\title{
PENGGUNAAN METODE FMECA (FAILURE MODES EFFECTS CRITICALITY ANALYSIS) DALAM IDENTIFIKASI TITIK KRITIS DI INDUSTRI KEMASAN
}

\section{USE OF THE METHOD FMECA (FAILURE MODES EFFECTS CRITICALITY ANALYSIS) IN THE IDENTIFICATION OF CRITICAL POINT IN INDUSTRIAL PACKAGING}

\author{
Arif Rahman ${ }^{1 *}$ dan Farah Fahma \\ ${ }^{1)}$ Program Studi Teknik Industri, Universitas Indraprasta PGRI, Jakarta, Indonesia \\ ${ }^{2)}$ Departemen Teknologi Industri Pertanian, IPB University, Bogor, Indonesia \\ Email: arif.rahman0876@gmail.com ${ }^{1}$, farah_fahma@apps.ipb.ac.id ${ }^{2}$ \\ Makalah: Diterima 27 November 2020; Diperbaiki 20 April 2021; Disetujui 30 April 2021
}

\begin{abstract}
PT. XYZ is a company engaged in packaging, especially for pharmaceuticals. The company has recorded an overall defective product known as end to end waste. During 2019 the average end to end waste was 12.37\%, while the target of company management was $9 \%$. The objective of this research is to minimize defective products and to find out what types of defects occur in the production process. The method used in this research is FMECA (Failure Modes, Effects and Critically Analysis), which is the development of the FMEA (Failure Mode and Effect Analysis) method which functions to make analyzes from production tools or processes, types of defects to the effects that arise as a result. of the defect, but also to determine the critical point. The results of the analysis that has been carried out using the FMEA method with RPN (Risk Priority Number) calculations, then analysis with the Pareto diagram and criticality matrix, the researcher gets 10 priority failure modes, namely the machine often stops due to a lot of paper dust, too high piles, unstable colors because there is a change in ink, the non-stop feeder is damaged, the front lay and side lay are unstable from the printing process, the side lay sensor does not work, the actual chiller temperature with the display is not the same, the paper is untidy from the printing process, the paper is untidy from the calendering process, and the chiller is leaking. The researcher also gave recommendations, namely making a Standard Operation Procedure (SOP) for handling dusty paper, submitting complaints to suppliers regarding paper quality, providing a printing unit, and training for dusty paper handling.
\end{abstract}

Keywords: criticality matrix, FMECA, risk priory number, pareto diagram

\section{ABSTRAK}

PT. XYZ merupakan perusahaan yang bergerak di bidang kemasan khususnya untuk farmasi. Perusahaan telah mendata produk cacat secara keseluruhan yang disebut dengan end to end waste. Selama tahun 2019 ratarata end to end waste sebesar $12,37 \%$, sedangkan target dari manajemen perusahaan adalah $9 \%$. Tujuan dari penelitrian ini adalah untuk meminimalisir produk yang defect dan untuk mengetahui jenis-jenis defect apa saja yang terjadi pada proses produksi. Metode yang digunakan dalam penelitian ini adalah FMECA (Failure Modes, Effect and Critically Analysis), yang merupakan pengembangan dari metode FMEA (Failure Mode and effect Analysis) dimana berfungsi membuat analisa dari mulai alat atau proses produksi, jenis defect sampai dengan pengaruh yang muncul akibat dari defect tersebut, selain itu juga untuk menentukan titik kritis. Hasil dari analisa yang sudah dilakukan menggunakan metode FMEA dengan perhitungan RPN (Risk Priority Number), kemudian analisa dengan diagram pareto dan matriks kritikalitas maka peneliti mendapatkan 10 prioritas mode kegagalan, yaitu mesin sering berhenti karena banyak debu kertas, tumpukan terlalu tinggi, warna tidak stabil karena ada perubahan tinta, non stop feeder rusak, front lay dan side lay tidak stabil dari proses printing, sensor side lay tidak berfungsi, temperatur chiller aktual dengan display tidak sama, kertas tidak rapi dari proses printing, kertas tidak rapi dari proses calendering, dan chiller bocor. Peneliti juga memberikan rekomendasi yaitu pembuatan Standard Operation Procedure (SOP) penanganan kertas yang berdebu, menyampaikan keluhan ke suplier mengenai kualitas kertas, menyediakan sebuah unit printing, dan pelatihan untuk penanganan kertas yang berdebu.

Kata kunci: diagram pareto, FMECA, risk prioiry number, matriks kritikalitas

\section{PENDAHULUAN}

Produk yang berkualitas merupakan persyaratan bagi produsen supaya bisa diterima oleh pelanggan dan bisa memenangkan persaingan dengan kompetitor, dengan semakin ketatnya persaingan menyebabkan semua perusahaan bersaing untuk melakukan peningkatan kualitas, melakukan terobosan-terobosan perbaikan produk serta melakukan continuous improvement. PT. XYZ merupakan perusahaan kemasan dengan spesialisasi memproduksi kemasan untuk farmasi.

Berdasarkan data tahun 2019 bahwa jumlah produk yang cacat melebihi dari yang ditargetkan oleh pihak manajemen perusahaan. Perusahaan mendata produk cacat (defect) secara keseluruhan 
dari mulai awal proses produksi sampai dengan produk dikirim ke pelanggan yang disebut dengan end to end waste. Data produk defect dari januari sampai desember tahun 2019 rata-rata end to end waste adalah $12,37 \%$ sedangkan target end to end waste dari manajemen PT. XYZ adalah sebesar 9\%.

Dengan masih tingginya nilai end to end waste ini mendorong peneliti mencari faktor-faktor yang menyebabkan terjadinya produk defect tersebut. Ada beberapa metode yang bisa digunakan untuk menganalisa dan mencari penyebab terjadinya defect produk diantaranya adalah dengan metode FMEA, metode FTA, dan juga metode FMCEA. Metode yang pertama yaitu FMEA (Failure Mode Effect Analysis) adalah suatu metode kualitatif yang berfungsi untuk melakukan identifikasi kemungkinan-kemungkinan terjadinya kegagalan diakibatkan oleh alat, proses, dan juga system, sedangkan kalau metode FMECA (Failure Mode Effect and Critically Analysis) yaitu pengembngan dari metode FMEA dimana merupakan suatu metode kuantitatif yang berfungsi melakukan identifikasi potensi kegagalan dengan menambahkan analisa titik kritis dengan enggunakan matrik kritikalitas (Ibrahim et al., 2011).

Metode berikutnya adalah FTA (Fault Tree Analysis), yaitu suatu metode yang mampu menjelaskan secara sistematik faktor-faktor penyebab yang tidak diharapkan secara langsung menuju kegagalan, namun metode FTA ini juga belum sempurna karena memiliki sifat yang subjektif. (Pasaribu et al., 2017). Ruang lingkup metode FTA kurang luas, ditambah lagi saat proses perhitungan dibutuhkan keahlian yang harus kuat (Satriyo dan Puspitasari, 2017).

Dengan jumlah end to end waste yang tinggi di PT. XYZ yaitu 12,3\%, maka peneliti memutuskan FMECA (Failure Mode Effect and Critically Analysis) digunakan sebagai metode penelitian FMECA adalah metode hasil dari pengembangan dari metode sebelumnya yaitu FMEA. FMEA ini adalah salah satu metode yang tepat untuk menganalisa tingkat keandalan suatu produk dan juga proses (Puspitasari dan Martanto, 2014). Walaupun FMEA ini merupakan metode yang sudah tepat, namun masih mempunyai kelemahan yaitu penggunaannya yang kurang fleksibel dalam hal peningkatan desain. Saat ini pelanggan tentunya akan menuntut kepada para produsen untuk melakukan peningkatan kualitas terhadap produk yang dihasilkan, selain menuntut kualitas produk yang tinggi produsen juga harus menghasilkan produk yang handal.

Metode FMEA memberikan tools yang sederhana dan mudah untuk diterapkan dalam hal menentukan risiko yang memiliki potensi yang besar dan perlu dilakukan tindakan preventive supaya bisa mencegah timbulnya masalah. Tujuan dari pengembangan metode ini adalah untuk memastikan produk akan mencapai persyaratan yang ditetapkan (Ambekar et al., 2013).
Alasan dipilihnya metode FMECA dalam penelitian ini karena FMECA adalah suatu metode yang menggabungkan antara metode FMEA ditambahkan dengan analisa titik kritis yang menggunakan matriks kritikalitas, tujuannya adalah untuk membuat analisa potensi risiko yang kemungkinan bisa terjadi pada alat, proses, dan juga sistem, FMECA diaplikasikan untuk melaukan identifikasi faktor-faktor yang bisa menyebabkan kegagalan, dan melakukan indentifikasi dampak terhadap hasil proses produksi, dan melakukan identifikasi tindakan preventive untuk menghindari terjadinya kegagalan (Putra et al., 2017).

Metode FMECA ini juga merupakan metode yang utama untuk mengoptimalkan fungsi dari pemeliharaan. Selain itu FMECA dapat menghasilkan sebuah sistem yang handal yang bisa meminimalisir terhadap kegagalan, dan juga mampu menjaga komponen dan fungsi bisa terkontrol dengan mudah. FMECA ini adapat diaplikasikan pada hal-hal yang penting, untuk mendominasi kegagalan, khusunya untuk faktor-faktor yang mempunyai titik kritis yang paling tinggi. Menurut Ilyas (2015) FMECA adalah suatu metode yang sudah disesuaikan dalam beberapa cara untuk bermacam-macam keperluan. Keuntungan menggunakan metode FMECA ini dapat meningkatkan desain produk dan proses, sehingga dapat menghasilkan alat atau proses yang lebih handal, produk yang berkualitas tinggi, keamanan produk lebih meningkat, pelanggan menjadi lebih puas terhadap kualitas dan pelayanan, juga biaya bisa menjadi lebih murah.

FMECA merupakan metode yang memiliki 2 analisa, yaitu menggunakan metode FMEA (Failure Mode Effect Analysis) dan metode analisa titik kritis (Critically Analysis). Metode FMEA fungsinya untuk melakukan evaluasi terhadap beberapa risiko yang berasal dari kemungkinan-kemungkinan terjadinya masalah dengan menggunakan beberapa cara atau metode. Metode yang biasanya digunakan adalah dengan cara perhitungan Risk Priority Number (RPN). Untuk mengaplikasikan metode ini dibutuhkan bantuan dari tim pakar untuk menentukan nilai variabel-varibel yang dibutuhkan pada saat perhitungan RPN, tim pakar ini berasal dari PT. XYZ yang memiliki kemampuan analisa untuk mengevaluasi penyebab-penyebab kegagalan dan efek yang dihasilkan. Tugas utama dari tim pakar ini adalah menentukan tingkat keparahan (severity), tingkat seberapa banyak gangguan yang dapat menyebabkan sebuah kegagalan (occurance), dan tingkat deteksi (detection). Perhitungan RPN adalah hasil perkalian dari severity, occurance, dan detection. (Sahoo et al., 2014).

Dengan digunakannya metode FMECA ini diharapkan dapat mencapai tujuan yang diinginkan oleh peneliti yaitu: melakukan identifikasi produk defect yang mengakibatkan nilai end to end waste tinggi di PT. XYZ dan mencari penyebabnya, menentukan nilai dari titik kritis (RPN) untuk 
menentukan prioritas kegagalan yang terjadi pada saat proses produksi kemasan, dan dapat menentukan rekomendasi yang harus dilakukan oleh PT. XYZ dari masing-masing mode kegagalan di setiap proses produksi kemasan.

\section{METODE PENELITIAN}

Dengan kondisi data yang ada di PT. XYZ menuntut metode yang digunakan dalam penelitian ini adalah memakai metode semi kuantitatif. FMECA merupakan metode yang termasuk dalam kategori kulitatif dalam berbagai bidang. Dengan menggunakan metode FMECA ini keuntungannya adalah mendapatkan pengetahuan yang fokus mengenai fungsi dan hubungan interaksi dari suatu sistem, dengan analisa yang dilakukan secara sistematis hubungan sebab dan akibat. Informasi yang diperoleh berguna sebagai bagian dari manajemen risiko, dan hal yang menjadi perhatian adalah tingkat keandalan sistem operasional, hal ini dapat digunakan untuk mengetahui elemen yang paling penting (fungsi dan komponen yang digunakan PT. XYZ), menentukan dan melakukan evaluasi peringkat kelemahan, kesalahan penggunaan sistem, menentukan dan melakukan evaluasi terhadap titiktitik kritis dan membuat rekomendasi untuk PT. XYZ.

Kelebihan dari metode semi kuantitatif menurut Bakhiar (2017) yaitu tingkat keakuratannya lebih bagus jika dibandingkan dengan metode kualitatif, selain itu juga metode ini mempunyai kelebihan lain yaitu lebih mudah dan cepat dari pada metode kuantitatif, tetapi metode semi kauantitatif ini juga memiliki kekurangan yaitu kurang akurat jika dibandingkan dengan metode kuantitatif, dan skala yang dipakai adalah skala yang harus tepat dalam penentuan tingkat risiko. Analisa menggunakan metode semi kuantitatif dilakukan dengan cara pengamatan di lapangan produksi, dan proses wawancara dengan supervisor dan manajer produksi, selain itu juga dilakukan wawancara dengan supervisor dan manajer QC. Penelitian ini dilakukan 3 bulan, dari januari sampai maret tahun 2020 di PT. XYZ yang berlokasi di Bekasi-Jawa Barat. Data yang didapatkan dari hasil pengamatan dan wawancara adalah data mode kegagalan atau data defect yang menyebabkan end to end waste tinggi, dan data severity, occurrence, dan detection dari setiap mode kegagalan yang digunakan untuk menghitung nilai Risk Priority Number (RPN) .

Teknik pengumpulan data dalam penelitian ini adalah dengan proses pengumpulan data, yaitu data penyebab terjadinya produk defect di setiap proses produksi dari mulai proses printing sampai ke proses finishing, yang digunakan dalam tahapan analisa menggunakan metode FMECA dan analisa titik krits. Pada saat proses analisa FMEA ini khususnya pada saat perhitungan nilai RPN analisisnya menggunakan sistem pakar dan menggunakan metode FMECA. Sistem pakar adalah salah satu cabang dari Artificial
Intelligence (AI) yang menggunakan pengetahuan secara luas yang dimiliki oleh manusia khusus untuk menyelesaikan masalah. (Badariah et al., 2016). Seorang pakar adalah orang yang memiliki keahlian khusus di bidang tertentu, yaitu pakar yang mempunyai pengetahuan atau kemampuan khusus yang tidak dimiliki orang lain di bidang yang dikuasainya. Secara garis besar menurut Ibrahim et al. (2011) analisa FMECA terbagi menjadi 2 proses, yaitu:

1. Analisis FMEA (Failure Modes and Effect Analysis/FMEA). Analisa FMEA terdiri dari beberapa tahap yaitu: analisa titik-titik kegagalan (produk defect). Di tahap awal ini yang dilakukan adalah: menetapkan ID, menetapkan titik-titik kegagalan dan yang menyebabkan terjadinya kegagalan. Evaluasi mengenai titik-titik kegagalan pada penelitian ini dilakukan dengan perhitungan nilai Risk Priority Number (RPN). RPN adalah hasil perkalian dari Severity (S), Occurance (O) dan Detection (D). Menurut Andiyanto, dkk (2017) Severity adalah tinkat keparahan akibat dari proses yang gagal pada proses produksi dan aktivitas yang ada di pabrik lainnya. Detection adalah kemampuan mendeteksi kegagalan proses yang bisa diketahui sebelum terjadinya kegagalan tersebut. Occurance adalah menentukan nilai gangguan yang bisa mengakibatkan kegagalan proses produksi.

2. Analisis kritikalitas (Critical Analysis/CA). Analisis kritikalitas menggunakan matriks kritikalitas (Criticality Matrix). Analisis krikitalitas dilakukan melalui beberapa tahap yaitu:

a. Menentukan tingkat keparahan (Severity) dan juga tingkat occurance

b. Melakukan perhitungan nilai Risk Priority Number (RPN) pada setiap titik kegagalan

c. Menempatkan setiap titik kegagalan pada matriks krtikalitas dengan memperhatikan nilai severity dan occurance seperti yang ada di gambar 2. Jika posisi titik kegagalan cenderung berada di sebelah kiri kolom maka artinya titik kegagalannya semakin tinggi, dan jika titik kegagalan berada di posisi semakin keatas baris maka tingkat kegagalannya juga semakin tinggi, dan ini berlaku sebaliknya jika posisinya semakin ke kanan kolom dan dibawah baris maka tingkat kegagalannya semakin rendah.

Berikut ini adalah alur proses metode yang digunakan dalam penelitian ini adalah sebagai berikut: data dikumpulkan dengan cara pengamatan di lapangan dan wawancara kepada tim pakar perusahaan untuk mengetahui mode kegagalan yang terjadi pada saat proses produksi PT. XYZ, langkah selanjutnya adalah perhitungan nilai RPN. Nilai RPN didapatkan setelah tim pakar menentukan rating 
severity, occurrence, dan detection. Pada tahap ini peneliti merangkum semua potensi yang mungkin akan terjadi kegagalan dan juga mendata kegagalan yang sudah pernah terjadi di perusahaan. Pada saat proses mendata ini, peneliti dibantu oleh para pakar dari perusahaan. Pakar perusahaan ini yang menentukan nilai severity, occurance, dan detection. Pakar dari perusahaan ini terdiri dari supervisor produksi, manajer produksi, supervisor QC, dan manajer QC. Mereka merupakan sejumlah orang yang memiliki kemampuan lebih di bidangnya yaitu di industri kemasan sehingga pendapatnya dapat digunakan untuk menerapkan metode FMECA berdasarkan sistem pakar. Menurut Priyandari et al. (2018) menyatakan pakar dapat ditentukan berdasarkan pengalaman dari staf yang sudah berkecimpung lama dengan proses produksi di perusahaan.

Langkah selanjutnya setalah ada nilai RPN adalah melakukan prioritas dengan cara mengurutkan titik kegagalan dari terbesar ke yang terkecil menggunakan diagram pareto. Keuntungan dari menggunakan diagram pareto adalah diagram ini mampu menyelesaikan masalah-masalah yang besar diubah menjadi beberapa bagian kecil dan bisa memilah titik kegagalan yang memiliki kontribusi besar. Tujuannya adalah untuk menghasilkan perbaikan yang optimal dengan menggunakan sumber daya yang ada dengan cara fokus terhadap perbaikan yang menjadi prioritas. Prinsip dari diagram pareto adalah fokus pada titik kegagalan yang kritis yang menyumbang masalah terbesar.

Hasil dari proses prioritas menggunakan diagram pareto didapatkan 10 mode kegagalan, setelah itu dilakukan kembali proses pemprioritasan dengan menggunakan matriks kritikalitas. Matriks kritikalitas ini digunakan jika ada nilai RPN yang sama sehingga perlu dilakukan pemprioritasan dengan cara memperhatikan nilai dari severity dan occurance. Dari hasil pemprioritasan dengan matriks kritikalitas tersebut maka didapatkan urutan prioritas mode kegagalan terbaru, langkah selanjutnya adalah menentukan penyebab terjadinya kegagalan dengan menggunakan metode fishbone diagram atau cause and effect diagram. Kemudian untuk membuat rekomendasi digunakan metode $5 \mathrm{~W}+1 \mathrm{H}$.

\section{HASIL DAN PEMBAHASAN}

\section{Analisis Mode Kegagalan dan Perhitungan RPN}

Untuk melakukan evaluasi titik kegagalan bisa dilakukan dengan dua cara yaitu Criticality Number (CN) atau menggunakan Risk Priority Number (RPN) (Andiyanto, dkk. 2017). Penentuan nilai RPN dilakukan dengan cara perkalian antara nilai severity, occurrence, dan detection dimana nilai tersebut hasil dari identifikasi dari setelah melakukan pengamatan dan wawancara dengan bagian produksi dan Quality Control (QC). Adapun perhitungan dari Risk Priority Number (RPN) adalah hasil perkalian dari Severity (S), Occurrence $(O)$, dan Detection (D).

$$
\mathrm{RPN}=\mathrm{S} \times \mathrm{O} \times \mathrm{D}
$$

Pada Tabel 1 berikut ini adalah nilai dari perhitungan RPN. Pada tabel ini dapat dilihat ada beberapa titik kegagalan di setiap alat atau mesin. Hasil nilai RPN beserta rincian nilai severity, occurance, dan detection

Tabel 1. Nilai Risk Priority Number (RPN) dan Setiap Mode Kegagalan

\begin{tabular}{|c|c|c|c|c|c|c|}
\hline $\begin{array}{l}\text { Nama } \\
\text { Alat/Proses }\end{array}$ & $\begin{array}{l}\text { No } \\
\text { Identitas }\end{array}$ & Mode Kegagalan & Severity & Occurance & Detection & RPN \\
\hline \multirow[t]{3}{*}{ Chiller } & 1.1 & Alat kontrol alkohol error & 4 & 5 & 5 & 100 \\
\hline & 1.2 & Chiller bocor & 5 & 7 & 5 & 175 \\
\hline & 1.3 & $\begin{array}{l}\text { Temperatur chiller aktual dengan } \\
\text { display tidak sama }\end{array}$ & 7 & 5 & 6 & 210 \\
\hline \multirow[t]{3}{*}{ Printing } & 2.1 & $\begin{array}{l}\text { Warna tidak stabil karena ada } \\
\text { perubahan jenis tinta }\end{array}$ & 7 & 7 & 6 & 294 \\
\hline & 2.2 & $\begin{array}{l}\text { Mesin sering berhenti karena banyak } \\
\text { debu kertas }\end{array}$ & 7 & 8 & 5 & 280 \\
\hline & 2.3 & Non stop feeder rusak & 7 & 7 & 5 & 245 \\
\hline \multirow[t]{4}{*}{ Diecutting } & 3.1 & $\begin{array}{l}\text { Front lay dan side lay tidak stabil dari } \\
\text { proses printing }\end{array}$ & 7 & 6 & 5 & 210 \\
\hline & 3.2 & $\begin{array}{l}\text { Tidak semua mesin diecutting memiliki } \\
\text { center line }\end{array}$ & 4 & 3 & 5 & 60 \\
\hline & 3.3 & Sensor side lay tidak berfungsi & 7 & 6 & 4 & 168 \\
\hline & 3.4 & $\begin{array}{l}\text { Kertas tidak rapi dari proses } \\
\text { sebelumnya (calendering) }\end{array}$ & 6 & 7 & 4 & 168 \\
\hline \multirow[t]{4}{*}{ Finishing } & 4.1 & Cutting mark tidak jelas & 4 & 4 & 6 & 96 \\
\hline & 4.2 & Pisau tumpul & 5 & 5 & 5 & 125 \\
\hline & 4.3 & Tumpukan terlalu tinggi & 7 & 8 & 4 & 224 \\
\hline & 4.4 & $\begin{array}{l}\text { Kertas tidak rapi dari proses } \\
\text { sebelumnya (printing) }\end{array}$ & 7 & 4 & 5 & 140 \\
\hline
\end{tabular}




\section{Analisa Prioritas Mode Kegagalan}

Untuk menentukan pemilihan mode kegagalan maka harus ditentukan terlebih dahulu prioritas mode kegagalannya, untuk menentukan prioritas kegagalan ini diperlukan diagram pareto. Fungsi dari diagram pareto ini adalah untuk mengurutkan tingkat kegagalan dari yang terbesar sampai ke yang terkecil, dimulai dari sebelah kanan diagram adalah yang tebesar dan yang terkecii berada di sebelah kiri diagram. Dengan urutan seperti itu memudahkan untuk menentukan titik kegagalan yang prioritas untuk dikaji mencari penyebab terjadinya kegagalan tersebut. Data yang diperoleh Dari PT. XYZ adalah mode kegagalan berjumlah 14 mode kegagalan. Dari 14 titik kegagalan yang dapat dilihat pada Tabel 1 kemudian langkah selanjutnya adalah menentukan prioritas utama titik kegagalan dengan menggunakan diagram pareto seperti terlihat pada Gambar 1.

Dari hasil diagram pareto di atas, bisa dilihat mode kegagalan terbesar yang berada di sebelah kiri diagram sampai mode kegagalan yang terendah berurutan dari kiri ke kanan di diagram pareto. Supaya lebih fokus terhadap proses perbaikan mode kegagalan, maka ditentukan 10 prioritas mode kegagalan yang ditentukan dari 10 terbesar mode kegagalan yang ada di diagram pareto. Berikut adalah 10 prioritas titik kegagalan yang ditampilkan pada Tabel 2.

\section{Matriks Kritikalitas}

Fungsi dari matriks kritikalitas adalah untuk menentukan prioritas mode kegagalan yang didasarkan pada tingkat keparahan dan tingkat kejadiannya, jika ada nilai RPN yang sama maka untuk menentukan mode kegagalan yang prioritas adalah berdasarkan nilai severity dan occurance. Setelah menggunakan diagram pareto di atas, didapatkan 10 prioritas utama mode kegagalan yang harus segera diperbaiki. Langkah selanjutnya adalah dari hasil analisa diagram pareto yang sudah didapatkan sebanyak 10 mode kegagalan tersebut kemudian dilakukan penilaian ulang lagi dengan memperhitungkan nilai severity dan occurrence. Dengan menggunakan matriks kritikalitas, akan sangat jelas jika ada dua titik kegagalan yang mempunyai nilai RPN yang sama, contohnya adalah pada titik kegagalan (3.3) sensor side lay tidak berfungsi dengan (3.4) kertas tidak rapi dari proses calendering.

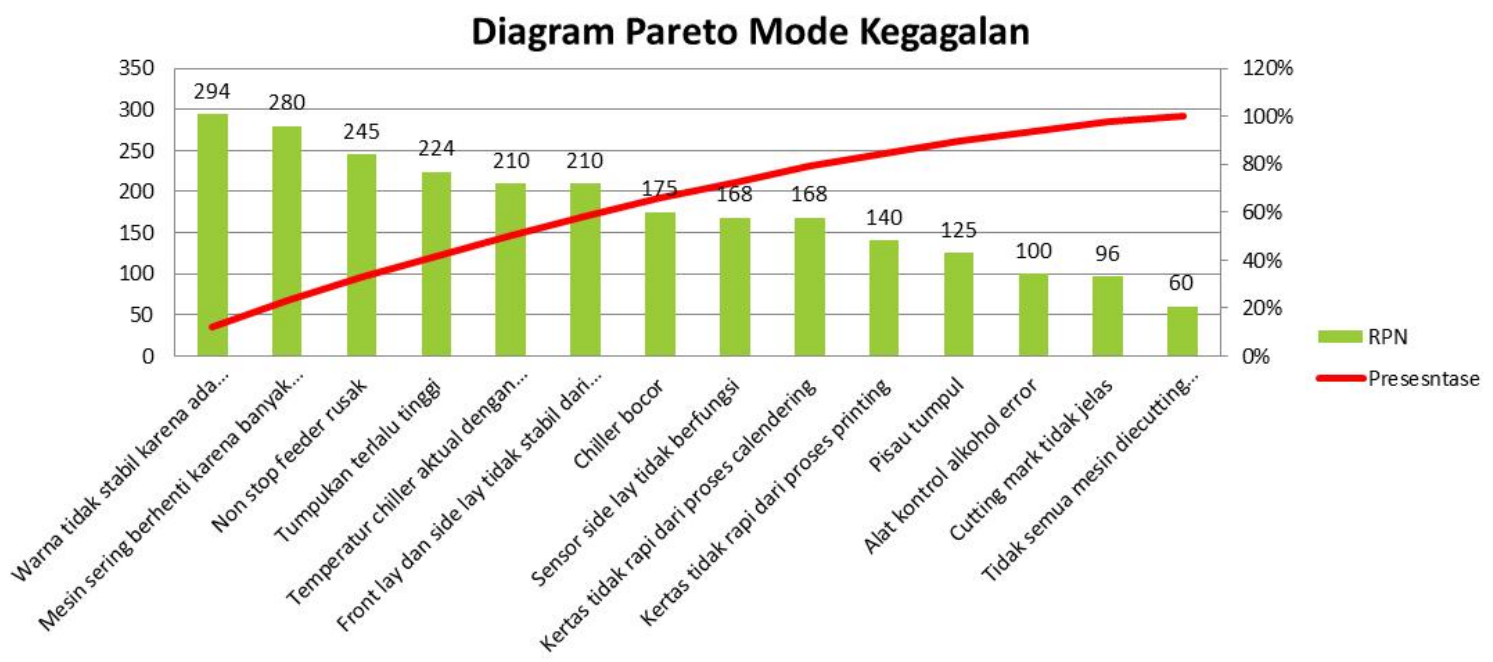

Gambar 1. Diagram Pareto Mode Kegagalan

Tabel 2. Prioritas mode kegagalan dari diagram pareto

\begin{tabular}{clc}
\hline No. Identitas & \multicolumn{1}{c}{ Mode Kegagalan } & RPN \\
\hline 2.1 & Warna tidak stabil karena ada perubahan jenis tinta & 294 \\
2.2 & Mesin sering berhenti karena banyak debu kertas & 280 \\
2.3 & Non stop feeder rusak & 245 \\
4.3 & Tumpukan terlalu tinggi & 224 \\
1.3 & Temperatur chiller aktual dengan display tidak sama & 210 \\
3.1 & Front lay dan side lay tidak stabil dari proses printing & 210 \\
1.2 & Chiller bocor & 175 \\
3.3 & Sensor side lay tidak berfungsi & 168 \\
3.4 & Kertas tidak rapi dari proses calendering & 168 \\
4.4 & Kertas tidak rapi dari proses printing & 140 \\
\hline
\end{tabular}


Kedua titik kegagalan tersebut mempunyai nilai detection yang sama yaitu 4 , tetapi salah satunya mempunyai nilai severity 7 dan nilai occurance 6 untuk sensor side lay tidak berfungsi, sedangkan untuk kertas tidak rapi dari proses calendering memiliki nilai severity 6 dan occurance 7 . Kedua mode kegagalan tersebut memiliki nilai RPN yang sama, yaitu 168. Maka dengan menggunakan matriks kritikalitas dan menempatkan nilai severity dan occurance titik kegagalan yang memiliki nilai RPN yang sama tersebut maka akan terlihat jelas jika titik kegagalan yang memiliki nilai severity 7 merupakan prioritas utama yang harus dilakukan tindakan korektif. Matriks kritikalitas dari titik-titik kegagalan disajikan pada Gambar 2.

Dari grafik kritikalitas mode kegagalan tersebut terdapat 10 mode kegagalan yang menjadi prioritas untuk dilakukan tindakan korektif. Dasar dari penentuan 10 mode kegagalan ini berdasarkan nilai severity dan occurance. Sepuluh Mode kegagalan tersebut disajikan pada Tabel 3.

\section{Pembahasan}

Dari hasil pehitungan nilai RPN, ada 14 mode kegagalan berdasarkan data yang diperoleh dari PT. XYZ. Dari hasil perhitungan RPN ini kemudian di analsia menggunakan diagram pareto. Prinsip diagram pareto memfokuskan upaya pada "masalah yang kritis" dengan cara mengurutkan mode kegagalan yang terbesar sampai yang terkecil. Hasil dari analisa dengan diagram pareto maka didapatkan prioritas 10 mode kegagalan yang utama yaitu warna tidak stabil karena ada perubahan jenis tinta, mesin sering berhenti karena banyak debu kertas, non stop feeder rusak, tumpukan terlalu tinggi, temperatur chiller aktual dengan display tidak sama, front lay dan side lay tidak stabil dari proses printing, chiller bocor, sensor side lay tidak berfungsi, kertas tidak rapi dari proses calendering, dan kertas tidak rapi dari printing. Setelah didapatkan 10 mode kegagalan hasil dari diagram pareto kemudian dilakukan pemprioritasan kembali dengan menggunakan matriks kritikalitas. Matriks kritikalitas ini berfungsi jika ditemukan nilai RPN yang sama sehigga perlu ditentukan kembali prioritasnya dengan memperhitungkan nilai severity dan occurance. Dari hasil diagram pareto dan juga mempertimbangkan matriks kritikalitas maka diperoleh urutan prioritas mode kegagalan, yaitu: mesin sering berhenti karena banyak debu kertas, tumpukan terlalu tinggi, warna tidak stabil karena ada perubahan tinta, non stop feeder rusak, front lay dan side lay tidak satbil dari proses printing, sensor side lay tidak berfungsi,temperatur chiller aktual dengan display tidak sama, kertas tidak rapi dari proses printing, kertas tidak rapi dari proses calendering, dan chiller bocor.

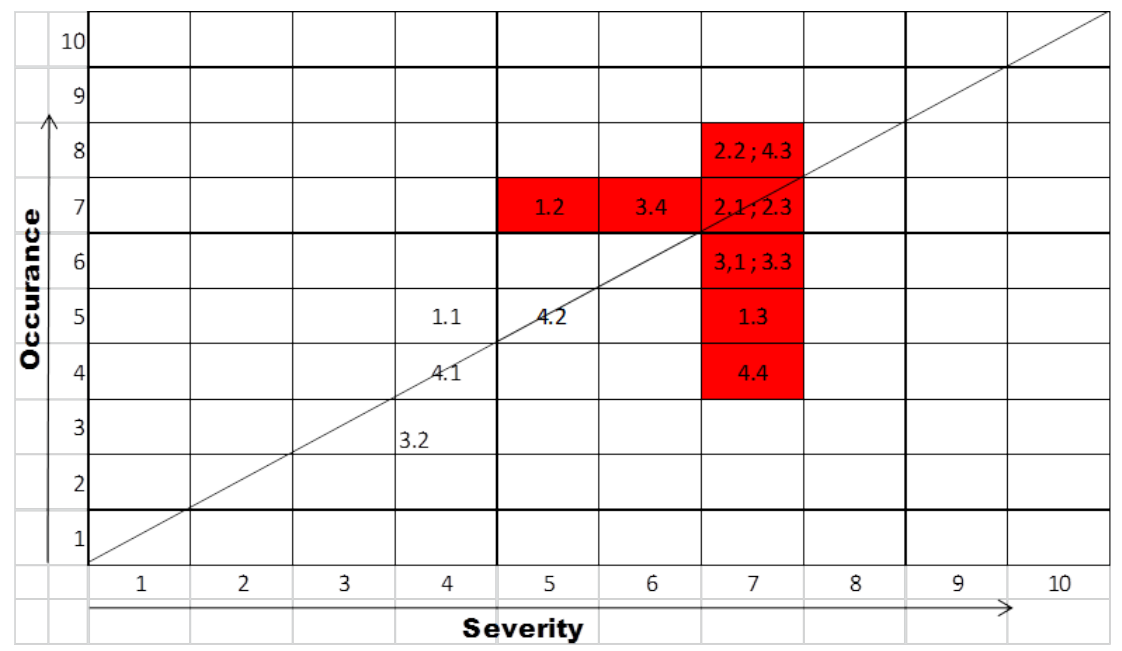

Gambar 2. Grafik Kritikalitas Mode Kegagalan

Tabel 3. Prioritas mode kegagalan dari grafik kritikalitas

\begin{tabular}{clc}
\hline No. Identitas & \multicolumn{1}{c}{ Mode Kegagalan } & RPN \\
\hline 2.2 & Mesin sering berhenti karena banyak debu kertas & 280 \\
4.3 & Tumpukan terlalu tinggi & 224 \\
2.1 & Warna tidak stabil karena ada perubahan jenis tinta & 294 \\
2.3 & Non stop feeder rusak & 245 \\
3.1 & Front lay dan side lay tidak stabil dari proses printing & 210 \\
3.3 & Sensor side lay tidak berfungsi & 168 \\
1.3 & Temperatur chiller aktual dengan display tidak sama & 210 \\
4.4 & Kertas tidak rapi dari proses printing & 140 \\
3.4 & Kertas tidak rapi dari proses calendering & 168 \\
1.2 & Chiller bocor & 175 \\
\hline
\end{tabular}


Berikutnya adalah melakukan analisa mencari penyebab-penyebab sehingga muncul mode-mode kegagalan diats dengan menggunakan metode fishbone diagram atau disebut juga cause and effect diagram.

\section{Cause and Effect Diagram}

Berdasarkan hasil dari matriks kritikalitas prioritas utama urutan nomor 1 adalah mesin sering berhenti karena debu kertas, mode kegagalan ini terjadi di proses printing, dimana pada saat proses printing menggunakan kertas dan saat proses produksi sering ditemukan kertas yang digunakan menghasilkan debu yang menyebabkan produk menjadi cacat karena ada debu kertas yang menempel di produk (kemasan), selain itu juga debu kertas ini juga menempel di unit mesin printing sehingga harus sering dibersihkan, dan saat membersihkanya mesin harus di stop terlebih dahulu. Dalam analisa cause and effect diagram atau fishbone diagram ini peneliti menganalisa dari beberapa faktor, yaitu: material, metode, manusia, dan mesin. Berikut ini adalah fishbone diagram dari mode kegagalan mesin sering berhenti karena debu kertas.

\section{Analisa 5W+1H}

Setelah menentukan titik-titik kegagalan yang sudah menajdi prioritas dari hasil analisa mengunakan diagram pareto dan matriks kritikalitas, maka selanjutnya adalah untuk membuat rekomendasi yang ditujukan utuk PT. XYZ dengan menggunakan metode $5 \mathrm{~W}+1 \mathrm{H}$. Tujuannya adalah membuat rencana kerja untuk meningkatkan kualitas berdasarkan (WHY-alasan, WHERE- lokasi, WHEN-kapan, WHO-orang, HOW-bagaimana)..

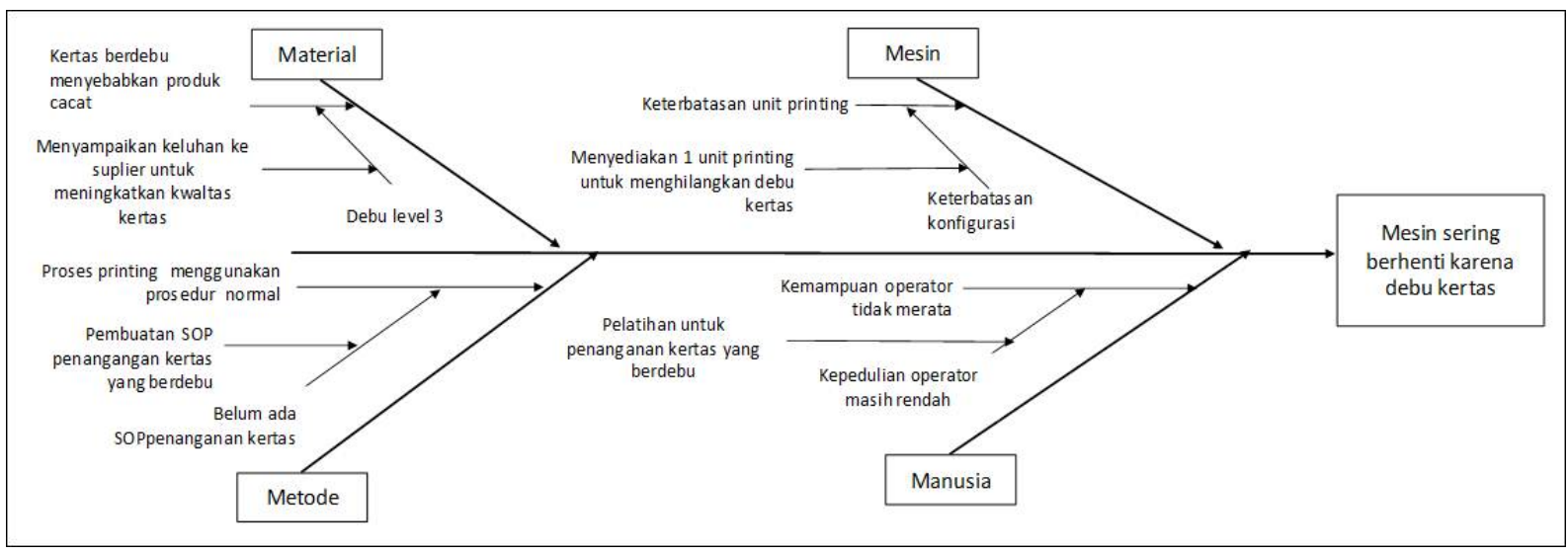

Gambar 3. Fishbone Diagram mode kegagalan mesin sering berhenti karena debu kertas

Tabel 4. Rekomendasi $5 \mathrm{~W}+1 \mathrm{H}$ pembuatan sop penanganan kertas yang berdebu

\begin{tabular}{ll}
\hline \multicolumn{1}{c}{$\mathbf{5 W + 1 H}$} & \multicolumn{1}{c}{ Jawaban } \\
\hline $\begin{array}{l}\text { Apa yang harus dilakukan? } \\
\text { kengapa harus dibuat SOP penangan }\end{array}$ & Membuat SOP penanganan kertas yang berdebu \\
$\begin{array}{l}\text { Dimana diperlukan SOP? } \\
\text { Siapa yang membuat SOP? }\end{array}$ & Pntuk mencegah produk cacat yang diakibatkan debu kertas \\
Kapan SOP bisa dilakukan? & Manager Produksi \\
Bagaimana membuat SOP untuk & Sebelum proses produksi dimulai (proses printing) \\
mencegah mesin berhenti karena debu & 1. Sebelum digunakan kertas dibersihkan menggunakan mesin \\
kertas? & $\begin{array}{l}\text { pile turner untuk menghilangkan debu } \\
\text { 2. Kertas yang sudah dibersihkan harus langsung digunakan } \\
\text { produksi untuk menghindari adanya debu dari lingkungan area }\end{array}$ \\
& produksi \\
3.Jika debu kertas masih muncul, maka kertas dibersihkan di \\
mesin printing dengan cara proses produksi tanpa tinta \\
(produksi kertas blank) \\
4. Pada saat proses printing berlangsung, operator harus selalu \\
mengecek sampling per-500 lembar \\
5. jika komponen blanket yang ada di unit printing sudah tebal \\
karena debu kertas yang menempel maka harus dibersihkan
\end{tabular}


Hasil dari analisa fishbone diagram diperoleh bahwa penyebab kegagalan mesin sering berhenti karena debu kertas rinciannya adalah sebagai berikut: dari faktor metode adalah: pembuatan SOP penanganan kertas yang berdebu, dari faktor Material adalah menyampaikan keluhan ke suplier untuk meningkatkan kualitas kertas, dari faktor Mesin adalah: menyediakan 1 unit printing untuk menghilangkan debu kertas, dan faktor Manusia adalah: pelatihan untuk penaganan kertas yang berdebu. Salah satu contoh rekomendasi perbaikan untuk mode kegagalan mesin sering berhenti karena debu kertas disajikan pada Tabel 4 sampai Tabel 7.

Tabel 5. Rekomendasi 5W+1H menyampaikan keluhan ke suplier

\begin{tabular}{|c|c|}
\hline $5 \mathrm{~W}+\mathbf{1 H}$ & Jawaban \\
\hline Apa yang harus dilakukan? & $\begin{array}{l}\text { Menyampaikan keluhan ke suplier untuk meningkatkan } \\
\text { kualitas kertas }\end{array}$ \\
\hline $\begin{array}{l}\text { Mengapa harus melakukan menyampaikan } \\
\text { keluhan ke suplier? }\end{array}$ & Untuk perbaikan kualitas kertas \\
\hline $\begin{array}{l}\text { Dimana diperlukan menyampaikan keluhan ke } \\
\text { suplier? }\end{array}$ & Pada saat ditemukan kertas berdebu \\
\hline Siapa yang membuat keluhan ke suplier? & Manager QC \\
\hline $\begin{array}{l}\text { Kapan menyampaikan keluhan ke suplier bisa } \\
\text { dilakukan? }\end{array}$ & Pada saat setelah dilakukan pengecekan oleh Incoming QC \\
\hline $\begin{array}{l}\text { Bagaimana menyampaikan keluhan ke suplier } \\
\text { untuk meningkatkan kualitas kertas? }\end{array}$ & $\begin{array}{l}\text { 1. Setiap ditemukan adanya kertas yang berdebu yang } \\
\text { melebihi level } 3 \text { maka harus disimpan buktinya (evidence) } \\
\text { 2. Buktinya harus berupa foto, vidio dan bukti fisik kertas } \\
\text { 3. Lengkapi dengan Lot Number dari kertasnya dan label } \\
\text { kertas dari suplier } \\
\text { 4. Setelah buktinya cukup maka manager QC membuat } \\
\text { surat keluhan/claim ke suplier dengan dilengkapi bukti- } \\
\text { bukti }\end{array}$ \\
\hline
\end{tabular}

Tabel 6. Rekomendasi 5W+1H menyediakan 1 unit printing

\begin{tabular}{|c|c|}
\hline $5 \mathrm{~W}+\mathbf{1 H}$ & Jawaban \\
\hline Apa yang harus dilakukan? & $\begin{array}{l}\text { Menyediakan } 1 \text { unit printing untuk menghilangkan } \\
\text { debu kertas }\end{array}$ \\
\hline $\begin{array}{l}\text { Mengapa harus menyediakan } 1 \text { unit printing untuk } \\
\text { menghilangkan debu kertas? }\end{array}$ & $\begin{array}{l}\text { Untuk menghilangkan debu kertas sebelum proses } \\
\text { produksi berlangsung }\end{array}$ \\
\hline $\begin{array}{l}\text { Dimana diperlukanmenyediakan } 1 \text { unit printing untuk } \\
\text { menghilangkan debu kertas? }\end{array}$ & Sebelum proses produksi dimulai \\
\hline $\begin{array}{l}\text { Siapa yangmenyediakan } 1 \text { unit printing untuk } \\
\text { menghilangkan debu kertas? }\end{array}$ & Manager Produksi \\
\hline $\begin{array}{l}\text { Kapan menyediakan } 1 \text { unit printing untuk } \\
\text { menghilangkan debu kertas? }\end{array}$ & Pada saat sebelum proses printing \\
\hline \multirow[t]{3}{*}{$\begin{array}{l}\text { Bagaimana menyediakan } 1 \text { unit printing untuk } \\
\text { menghilangkan debu kertas? }\end{array}$} & $\begin{array}{l}\text { 1. Untuk mesin printing yang memiliki konfigurasi } 7 \\
\text { warna/unit printing, maka disiapkan } 1 \text { unit printing } \\
\text { urutan pertama untuk digunakan menghilangkan debu } \\
\text { kertas sedangkan unit yang lainnya digunakan untuk } \\
\text { proses produksi }\end{array}$ \\
\hline & $\begin{array}{l}\text { 2. Jika spesifikasi produk membutuhkan sampai } 7 \\
\text { unit warna atau lebih maka proses produksi dilakukan } \\
2 \text { kali proses termasuk untuk menghilangkan debu } \\
\text { kertas }\end{array}$ \\
\hline & $\begin{array}{l}\text { 3. Unit printing yang digunakan untuk } \\
\text { menghilangkan debu tidak diberikan tinta sehingga } \\
\text { kertas masih blank }\end{array}$ \\
\hline
\end{tabular}


Tabel 7. Rekomendasi $5 \mathrm{~W}+1 \mathrm{H}$ pelatihan untuk penaganan kertas yang berdebu

\begin{tabular}{|c|c|}
\hline $5 \mathrm{~W}+1 \mathrm{H}$ & Jawaban \\
\hline Apa yang harus dilakukan? & Pelatihan untuk penanganan kertas yang berdebu \\
\hline $\begin{array}{l}\text { Mengapa harus melakukan pelatihan penanganan } \\
\text { kertas yang berebu? }\end{array}$ & $\begin{array}{l}\text { Untuk pemahaman operator bagaimana penanganan } \\
\text { terhadap kertas yang berdebu }\end{array}$ \\
\hline $\begin{array}{l}\text { Dimana diperlukan pelatihan penanganan kertas yang } \\
\text { berdebu? }\end{array}$ & Sebelum proses produksi dimulai \\
\hline $\begin{array}{l}\text { Siapa yang membuat pelatihan penanganan kertas } \\
\text { yang berdebu? }\end{array}$ & Manager Produksi \\
\hline $\begin{array}{l}\text { Kapan menyampaikan pelatihan penangan kertas } \\
\text { yang berdebu? }\end{array}$ & Pada saat sebelum proses printing \\
\hline \multirow[t]{7}{*}{$\begin{array}{l}\text { Bagaimana melakukan pelatihan penanganan kertas } \\
\text { yang berdebu? }\end{array}$} & $\begin{array}{l}\text { 1. Pelatihan penangan kertas yang berdebu ini } \\
\text { diberikan kepada operator bagian printing }\end{array}$ \\
\hline & 2. Materi pelatihan yang disampaikan oleh Manager \\
\hline & Produksi harus sesuai dengan SOP Penanganan \\
\hline & Kertas yang Berdebu \\
\hline & 3. Untuk memudahkan operator dalam pelatihan \\
\hline & $\begin{array}{l}\text { pelatihan dilengkapi dengan contoh dan batasan- } \\
\text { batasan debu kertas yang mempengaruhi kualitas } \\
\text { produk }\end{array}$ \\
\hline & $\begin{array}{l}\text { 4. Pada akhir pelatihan, harus dilakukan test untuk } \\
\text { mengetahui daya tangkap operator dalam mengikuti } \\
\text { pelatihan }\end{array}$ \\
\hline
\end{tabular}

\section{KESIMPULAN DAN SARAN}

\section{Kesimpulan}

Berdasarkan pembahasan diatas maka peneliti menarik kesimpulan yaitu terdapat 10 mode kegagalan yang diprioritaskan yaitu mesin sering berhenti karena banyak debu kertas, tumpukan terlalu tinggi, warna tidak stabil karena ada perubahan tinta, non stop feeder rusak, front lay dan side lay tidak satbil dari proses printing, sensor side lay tidak berfungsi,temperatur chiller aktual dengan display tidak sama, kertas tidak rapi dari proses printing, kertas tidak rapi dari proses calendering, dan chiller bocor. Faktor utama yang menyebabkan terjadinya kegagalan/produk cacat pada proses produksi kemasan adalah diperlukan pembuatan SOP penanganan kertas yang berdebu, perlu disampaikan keluhan ke suplier untuk peningkatan kualitas kertas, perlu menyediakan 1 unit printing untuk menghilangkan debu kertas, dan diperlukan pelatihan kepada operator untuk penanganan kertas yang berdebu. Dengan menerapkan metode FMECA maka dapat mencegah risiko kegagalan yang bisa terjadi dan sebagai tahap awal untuk membuat perencanaan selanjutnya, sehingga setelah menerapkan metode FMECA dapat dilakukan evaluasi terhadap pencapaian end to end waste.

\section{Saran}

Perusahaan harus mencari alternatif suplier lain yang bisa memberikan kualitas kertas yang bagus, jika suplier lokal kualitasnya tidak memenuhi standar maka harus mencari suplier dari luar negeri.

\section{DAFTAR PUSTAKA}

Ambekar SB, Ajinkya E, dan Vivek S. 2013. A review: implementation of failure mode and Effect Analysis. International Journal Engineering and Innovative Technology 2(8):37-41.

Andiyanto S, Sutrisno A, dan Punuhsingon C. 2017. Penerapan metode FMEA (Failure Mode And Effect Analysis) untuk kuantifikasi dan pencegahan resiko akibat terjadinya lean waste. Jurnal Online Poros Teknik Mesin. 6(1): 45-57.

Badariah D, Sugiarto D, dan Anugerah C. 2016. Penerapan metode Failure Mode And Effect Analysis (FMEA) dan expert system (sistem pakar). Seminar Nasional Sains dan Teknologi 2016 Fakultas Teknik Universitas Muhammadiyah, Jakarta: Indonesia. 8 November 2016

Bakhtiar A, Pratiwi RD, dan Susanty A. 2017. Analisis kegagalan proses produksi bengkirai decking dengan metode FMEA (Failure Modes, Effects and Critically Analysis). Seminar dan Konferensi Nasional IDEC, Surakarta, Indonesia: 8-9 Mei 2017.

Ibrahim B, Jacoeb AM, dan Hesamestyna M. 2011. Penggunaan metode FMECA (Failure Modes, Effects and Critically Analysis) dalam identifikasi titik kritis tracebility industri pengolahan udang breaded. Quality 
Jurnal Manajemen dan Akutansi Untuk Meningkatkan Kualitas SDM. 1(5): 34-45.

Ilyas A, Arina F, dan Ferdinant PF. 2015. Pengukuran efektivitas mesin electric arc furnace 9 dengan Metode OEE dan perbaikan menggunakan metode FMECA di PT. XYZ. Jurnal Teknik Industri. 3(3): 1623.

Pasaribu HP. 2017. Metode Failure Mode And Effect Analysis (FMEA) dan Fault Tree Analysis (FTA) untuk mengidentifikasi potensi dan penyebab kecelakaan kerja pada proyek gedung. [Tesis]. Yogyakarta: Universitas Atmajaya Yogyakarta.

Priyandari Y, Zakaria R, Syakura A. 2017. Sistem pakar pemupukan kelapa sawit menggunakan metode forward chaining. Jurnal Performa. 16(2): 98-106.

Puspitasari NB, Martanto A. 2014. Penggunaan FMEA dalam mengidentifikasi resiko kegagalan proses produksi sarung atm (alat tenun mesin) (Studi Kasus PT. Asaputex Jaya Tegal). Jurnal J@TI Undip. 2(9): 9398.
Putra HNE, Subukti A, dan Rachmad AN. 2017. Analisis risiko menggunakan metode FMCEA dan metode topsis untuk penentuan prioritas perbaikan pada steam turbine di perusahaan pembangkit listrik tenaga panas bumi. Proceeding 1st Conference on Safety Engineering and Its Application, Program Studi D4 Teknik Keselamatan dan Kesehatan Kerja - Politeknik Perkapalan Negeri, Surabaya, Indonesia: 19 Agustus 2017.

Sahoo T, Sarkar PK, dan Sarkar AK. 2014. Maintenance optimization for critical equipment in process industries based on FMECA method. International Journal Engineering and Innovative Technology 2(8): 107-112.

Satriyo B dan Puspitasari D. 2017. Analisis pengendalian kualitas dengan menggunakan metode fault tree analysis untuk meminimumkan cacat pada crank bed di lini painting PT. Sarandi Karya Nugraha. Industrial Engineering Journal Online. 6(1): 313-321. 